\title{
Collective capabilities shape the co-production of nature's contributions to people in the alpine agricultural system of the Maurienne valley, France
}

\author{
Julia Grosinger ${ }^{1,2}\left(\right.$ C) $\cdot$ Améline Vallet $^{4,5} \cdot$ Ignacio Palomo $^{3} \cdot$ Nicolas Buclet $^{1} \cdot$ Sandra Lavorel ${ }^{2,6}$
}

Received: 30 September 2020 / Accepted: 18 September 2021 / Published online: 3 November 2021

(c) The Author(s) 2021

\begin{abstract}
Nature's contributions to people (NCP) do not flow automatically from ecosystems to society, but they result from a coproduction process of interactions between societal and ecological systems. In this study, we used the collective capabilities approach to address the social dimensions of co-production of the material NCP of cheese. These are the benefits collective structures retrieve from social-ecological interactions that individuals could not have achieved on their own and which frequently exceed pure instrumental values. Collective structures mobilise different types of social capitals in order to generate these collective capabilities. Here, we specifically investigated linkages between collective capabilities and their contributions to common perceptions and local identities. We conducted 44 semi-structured interviews with two distinct different actors' groups in a French Alpine agricultural system surrounding the production of the quality labelled Beaufort cow cheese. We analysed the interviews qualitatively and conducted quantitative analyses as well as content and sentiment analysis to identify the different levels and types of collective investment mobilised by actors to generate collective capabilities. We found that collective capabilities involved in NCP co-production contributed to common perceptions and to specific dimensions of local identities. These can be viewed as the results of relational value construction. Further, the analysis suggests that collective capability relies on dense social interactions between actors that contribute to a good quality of life in itself. This study advances previous attempts to further investigate the role of intra-societal relations for NCP co-production.
\end{abstract}

Keywords Nature's contributions to people (NCP) - Collective capabilities · Local identities · Common perceptions · Co-production

Communicated by Sandrine Anquetin and accepted by Topical Collection Chief Editor Christopher Reyer

This article is part of the Topical Collection on Trajectories of socio-ecological change in mountains

Julia Grosinger

julia.grosinger@univ-grenoble-alpes.fr

Améline Vallet

ameline.vallet@agroparistech.fr

Ignacio Palomo

ignacio.palomo@univ-grenoble-alpes.fr

Nicolas Buclet

nicolas.buclet@univ-grenoble-alpes.fr

Sandra Lavorel

sandra.lavorel@univ-grenoble-alpes.fr

1 Institut de Géographie Alpine, PACTE, Sciences Po Grenoble, CNRS, Université Grenoble Alpes, 14 bis avenue Marie Reynoard, 38000 Grenoble, France
2 Laboratoire d'Ecologie Alpine, CNRS, Université Grenoble Alpes, Université Savoie Mont-Blanc, 38000 Grenoble, France

3 Univ. Grenoble Alpes, CNRS, IRD, Grenoble INP, IGE, 38000, Grenoble, France

4 Ecologie Systématique Evolution, AgroParisTech, CNRS, Université Paris-Sud, Université Paris-Saclay, Orsay, France

5 Cirad, CNRS, EHESS, Ecole Des Ponts ParisTech, CIRED, AgroParisTech, Université Paris-Saclay, Nogent-Sur-Marne, France

6 Manaaki Whenua Landcare Research, Lincoln, New Zealand 


\section{Introduction}

Ecosystems contribute to the multiple facets of people's good quality of life (Russell et al. 2013; Bratman et al. 2019). Nature's contributions to people (NCP) are subjective and highly context-dependent, and the understanding of their intricate material and non-material dimensions stands out as an enduring knowledge gap in social-ecological science (Díaz et al. 2018; Mastrángelo et al. 2019). The various dimensions of a good quality of life supported by nature relate to the satisfaction of human needs, including material NCP like food and shelter, and often highly subjective non-material NCP like belonging or identity (Max-Neef et al. 1989; Sen 2000). Therefore, a good quality of life is not exclusively quantified by material outcomes but also "on one's ability to choose the life one has reason to value" (Sen 2000), including in relation to others, as sense of place, belonging and identity are intrinsically collective. This is crucial to understand the complex choices people make, like trade-offs between dimensions of a good quality of life to align with their values (e.g. lower salary vs. more leisure time).

Recent conceptual frameworks representing social-ecological interactions highlight that NCP often require society's inputs, referred to as NCP co-production (Spangenberg et al. 2014; Díaz et al. 2015; Lescourret et al. 2015; Palomo et al. 2016). For example, water quality can be improved by ecosystems along with human infrastructure to benefit society (e.g. treatment plants, pipeline networks) (Palomo et al. 2016). Co-production processes and society's underpinning material (e.g. labour) and non-material (e.g. social capital) inputs need to be considered along the several steps from ecosystems to benefits to people (Fedele et al. 2017; Vallet et al. 2019a; Bruley et al. 2020). Co-production activities are tightly linked to actors' capabilities and their use and access to different capitals, also called resources (labour, technology, infrastructure,...) (Leach et al. 1999; Fischer and Eastwood 2016; Bruley et al., 2021a).

NCP co-production depends on individual actions or resources and on interactions among actors, along with collective capabilities. The concept of collective capabilities are the benefits people retrieve from social-ecological interactions that individuals could not have achieved on their own (Comim and Carey 2001; Ibrahim 2006). Social capital broadly describes social relations and interactions between people (Ibrahim 2006). In practice, collective capabilities can be achieved by collective investments to mobilise different forms of social capital. These underlying social structures and resources (e.g. social relations, social behaviour, collective structures, norms...) support activities (Ostrom 1999; Lehtonen 2004). For example, agricultural cooperatives are collective structures using social capital to bundle and provide services to farmers like marketing, sharing machines or equipment (e.g. irrigation systems), transformation facilities or procuring inputs. They allow farmers to specialise in some production activities to save transaction costs and can facilitate the local maintenance of agricultural activities (Ostrom 1990; Filippi and Torre 2003). Thus, collective structures can be identified as important engines to mobilise collective investments of social capital for collective capabilities in rural and marginalised landscapes including mountains (Ibrahim 2006; Pachoud et al. 2020).

Collective capabilities rely on common perceptions, shared interests and associated (less evident) identity-related dimensions like a sense of belonging to a place or group (Evans 2002; Pelenc et al. 2015). Common perceptions are the way in which people observe, understand, interpret and evaluate social-ecological systems and processes (Bennett 2016; Partelow et al. 2021). In southern Brazil, the involvement in producers' associations or cooperatives was found to be tightly related to common perceptions and farmers' local identities. Farmers were more likely to represent themselves through the typicality of their Serrano cheese and the belonging to Serrano and Rio Grande do Sul landscapes (Pachoud 2019).

Therefore, collective capabilities, common perceptions and local identities are dynamically interlinked. There are several published examples showing how common perceptions about natural resource management can encourage the implementation of more sustainable practices and policies (Frey and Berkes 2014; Forster et al. 2017; Dendoncker et al. 2018; Partelow et al. 2021). Indeed, NCP co-production exemplifies how collective capabilities, common perceptions and local identities drive (collective) action (Kramer and Tyler 1996; Rudd 2000). How these emerge from socialecological interactions, actors' organisation, cooperation or legacies are avenues for research in ecological economics and social ecology (Bennett 2016; Ballet et al. 2018). More precisely, there is a need to understand which kind and level of collective capabilities are useful for NCP co-production, and conversely how co-production contributes to local identities, and hence to a good quality of life (Cook et al. 2012; Lessmann and Rauschmayer 2013; Forsyth 2015).

Mountain social-ecological systems are exemplary to address these questions. First, mountain traditional farming systems can co-produce a diversity of NCP, while maintaining iconic biodiversity and cultural landscapes (MartínLópez et al. 2019; Vallet et al. 2019b). For instance, Alpine extensive livestock farming supports co-production of fodder for cheese or meat, along with aesthetic enjoyment, experiences of nature and hazard regulation (Grosinger et al. in review; Bruley et al., 2021b). Secondly, farmers in mountain areas are often organised collectively to be competitive, for instance through cooperative systems specialised in local products (Ricard 2015; Pachoud et al. 2020). Actors in mountain landscapes generate and establish collective capabilities, especially in the cheese production sector (Dissart 
2012; Pachoud et al. 2020). The cheese cooperative system is therefore highly relevant to analyse how common perceptions and collective capabilities relate to NCP co-production. As existing studies focus on the economic benefits of such collective institutions, this study aimed to bring new insights into sense of place, belonging and other identity-related non-material dimensions meaningful to Alpine traditional farming systems (Koohafkan and Altieri 2011; Buclet and Donsimoni 2018; Fagerholm et al. 2020; Petway et al. 2020).

In this study, we focused on co-production of the NCP of the cattle milk cheese "Beaufort" in the Maurienne valley (Savoy, France). The objectives of this paper are to (1) unravel co-production activities implemented by actors; (2) identify collective capabilities and associated collective investments of social capital mobilised by actors for different co-production activities and (3) analyse whether actors with specific perceptions and feelings about collective capabilities also have specific local identities. We conducted 44 semi-structured interviews with local actors that we analysed using text and sentiment analysis.

\section{Materials and methods}

\section{Study area}

The Maurienne valley is located in Savoy, a French region known for its traditional mountain agricultural systems. The 40,000 inhabitants live in predominantly rural settings; only three of the 62 municipalities exceed 2,000 inhabitants (SPM 2020). Population density is well below the average in the Alps (22 vs. 75 inhabitants $/ \mathrm{km}^{2}$ ) (Elmi 2018). The climate ranges from a humid pre-alpine climate in the west to a continental alpine climate in the east. Covering one third of the valley, grasslands are a characteristic land cover (Fig. 1). Consistent with other Alpine regions, a quarter of the work force is linked to winter tourism, with 24 skiing resorts. At the bottom of the valley, the industrial sector provides income for $19 \%$ of the working population. Livestock farming is the prevalent farming activity and represents with around 350 farms $2 \%$ of the total workforce (SPM 2020).

The Maurienne valley falls within the boundaries of the Protected Designation of Origin (PDO) label for the Beaufort cow cheese (INAO 2015). This EU-wide regulatory framework promotes specific agricultural products, their distinctive regional features and associated modes of production (Quiñones Ruiz et al. 2018). A consortium of fourteen cooperatives manages the production of the PDO cheese Beaufort (annual production: 5,000 t/year) in three adjacent valleys of Savoy. The Maurienne's three cooperatives with about 80 producers (900 t/year) are an integral part of this system since the registration of Beaufort in 1968. Each cooperative organises milk collection, transformation and sale. Milk production for Beaufort cheese within this cooperative system constitutes the major structuring agricultural activity in Maurienne and concerns 38\% of farms. Beef and small livestock (sheep, goat) are much less institutionalised (SPM

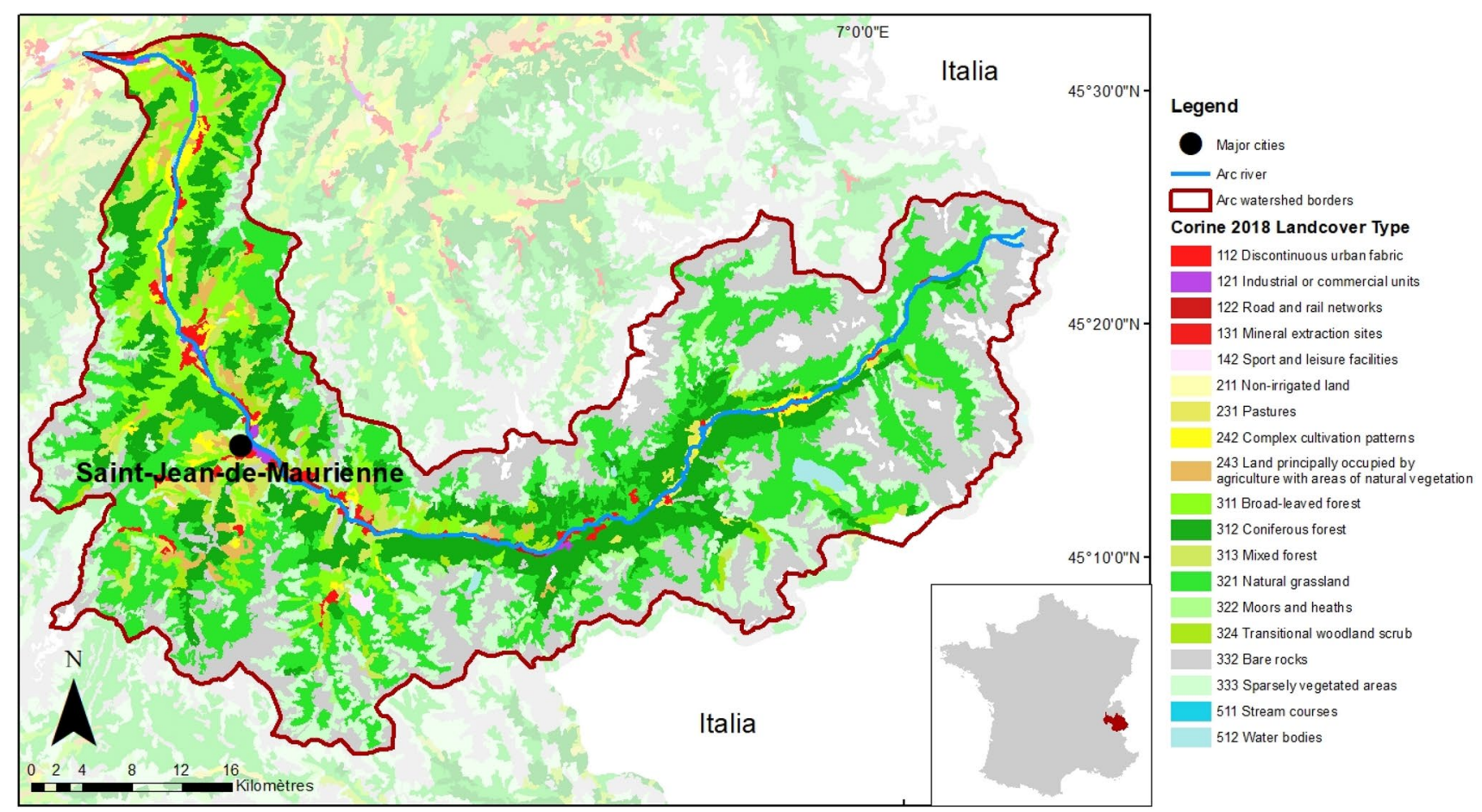

Fig. 1 Map of the Maurienne valley in the French Alps. Source: IGN-F (2006), Copernicus Land Monitoring Service (2018) and IGN-F (2019) 
Fig. 2 The three-step methodology to determine common perceptions about the Maurienne Alpine agricultural system

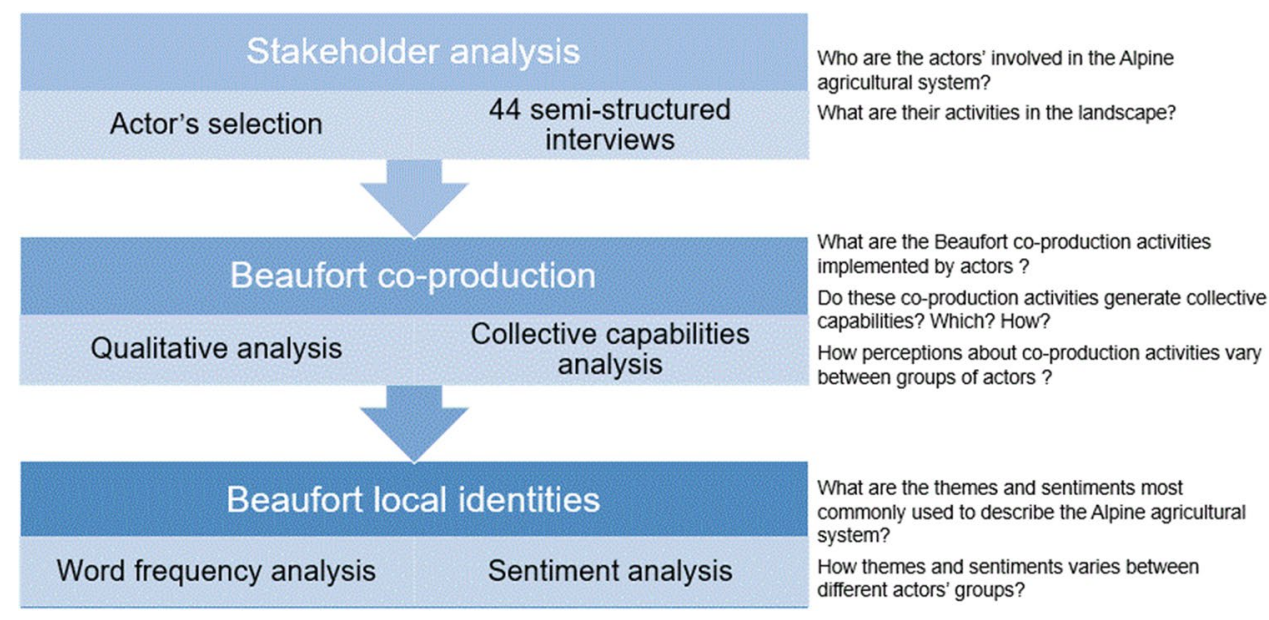

2020). The history of Beaufort as a high quality consumer brand dates back to the 1960s when local actors looked for an effective response to combat rural emigration and the associated decline of Alpine agriculture (Dubeuf 1996). Similar to other PDO cheese production systems, the cooperatives are currently associated within a consortium, which regulates and facilitates modes of production and market relations. The mandatory compliance to specification requirements protects the uniqueness of the product (INAO 2015; Lynch and Harvois 2016). These collectively agreed regulations are to various extents historical (limiting livestock to two regional breeds: "Tarine" and "Abondance"); economic (restricted milk quantity at cooperative and farm level) or technical (75\% of the forage originates from the valley). These various restrictions guarantee the uniqueness and homogeneity of the product (INAO 2015; Lynch and Harvois 2016).

\section{Overview of the approach}

We used a three-step methodology to analyse the collective capabilities mobilised along NCP co-production of Beaufort cheese and understand if well-perceived co-production activities also contribute to local identities (Fig. 2): (1) stakeholder analysis; (2) Beaufort co-production activities analysis and (3) description of the local identities surrounding the Beaufort production system in Maurienne. In order to highlight potential differences in perceptions, all analyses were replicated for two groups of actors, defined on whether they directly participate in the Beaufort production chain.

\section{Actor selection}

Stakeholder analysis supports the identification of actors and the analysis of their behaviour, concerns and roles (Reed et al. 2009). We defined relevant actors as the user groups who influence or benefit from Beaufort production in Maurienne (Reed et al. 2009; Herzog and Ingold 2019). This encompasses actors from the wider agricultural sector like regulatory authorities and agricultural associations and actors from the tourism and industrial sectors who indirectly derive benefits from Beaufort production. Ultimately, we identified around 400 actors relevant to Maurienne's Beaufort production system, among which three cooperatives, 10 agricultural associations, 62 municipalities, 355 farm holdings (of which 80 are cooperative members), 22 pastoral land associations, one major industrial actor, 24 tourism actors and 5 services of the regional authority. We restricted our analysis to 43 actors from this list (Supplementary Materials 1), in line with our resources. The 43 selected actors were identified based on a preliminary internet search of academic and grey literature and a brainstorming process with four academic experts of the region representing different disciplines. We then iteratively updated this list over the course of field research by purposive snowballing (Bryman 2016). The composition and distribution of the selected actors reflect to a certain extent the composition of the agricultural sector in Maurienne, so we consider the interview dataset as a representative sample of the 400 actors relevant to its Beaufort production system (SPM 2020).

We classified actors into two groups, to determine whether specific cooperative structures built around Beaufort production foster different perceptions of NCP co-production activities and the associated collective capabilities than actors not directly linked economically to the Beaufort production system. The first group, hereafter referred as "within Beaufort production" group (WB, $n=17$ ), included actors directly involved in the Beaufort production chain. It included eleven full-time farmers, eight of which with different roles in Beaufort production. The six remaining actors were full-time employees in cooperatives. Actors representing the interest of Beaufort farmers, like in agricultural associations or trading unions, were also included in this 
first group. In contrast, the second group hereafter referred to "outside Beaufort production" (OB, $n=27)$ represented actors who either benefit indirectly (e.g. by non-material aspects like landscape appearance, tourism) or who contribute or manage indirectly Beaufort production (e.g. managing pasture land, road infrastructure, knowledge sharing). For example, agricultural associations provide guidance, technical or administrative assistance to individual farmers, but do not interfere directly in the production chain. Actors of the OB group act in a social-ecological landscape shaped by Beaufort production that they influence indirectly through their action on land use (e.g. protection of biodiversity or cultural heritage, land consolidation). This group was composed of local and regional state institutions, agricultural associations and one industrial company and included two farmers outside of the Beaufort production system (beef and small livestock). It is worth noting that almost all farmers producing Beaufort cheese in the study area are affiliated to one of the three cooperatives: in 2019 there were only two farmers who produced Beaufort independently all-yearround, and ten seasonally.

\section{Data collection}

We conducted 44 semi-structured interviews, representing the 43 selected actors. We selected interviewees based on their involvement in their institutions. They included farmers, officials (e.g. agricultural chamber), collective institutions (e.g. associations for agricultural development, pastoral land associations) or skiing resorts (Supplementary Materials 1). For collective actors or regional authorities, we selected interviewees in either leading or managing positions, or actively involved in Beaufort production. For instance, we conducted interviews with chairs of six pastoral associations. Thirteen interviewees were full-time farmers. Consistent with other Alpine agricultural systems, most of them had representative, managing, leading or technical roles (often voluntary) in collective institutions (e.g. cooperatives, pastoral land associations), in addition to managing their farm (Schermer et al. 2010).

To elicit interviewees' perceptions of agriculture, semistructured interviews focused on the role and background of respective institutions, on their professional position, their perceptions and relations to the Maurienne agricultural landscape, including the agricultural sector and Beaufort production (Interview guide in Supplementary Materials 2). With institutional representatives, we specifically asked interviewees to explain the role of their organisation. Interviews took place from February to September 2019 in the actors' working environment, with an average duration of 60-90 min. We transcribed and uploaded the dataset of 350 pages in the original language (French) into the qualitative data analysis software NVivo, release 1.2 (QSR International 2020).

\section{Data analysis}

\section{Unravelling collective capabilities at different steps of Beaufort co-production}

We considered that NCP co-production follows three steps along the NCP cascade from ecosystems to society and good quality of life (Bruley et al. 2020). Co-production step 1 (CP1) refers to ecosystem biophysical management, like fertilisation. Co-production step 2 (CP2) refers to activities of extraction of material or non-material outputs from the social-ecological system, like milking or haymaking. Coproduction step $3(\mathrm{CP} 3)$ relates to translation to a final NCP benefit, e.g. milk, a transformed dairy product or to nature's appreciation and other non-material NCP.

Our analysis focused on deliberate co-production activities mentioned by actors from the two groups. First, we coded all co-production activities in NVivo, using a predefined typology. This typology was built using existing studies on co-production of agricultural NCP (Palomo et al. 2016; Vallet et al. 2019a; Bruley et al., 2021a). The typology was then iteratively improved while coding the interviews; the final version is provided in Supplementary Materials 3.

Then, for each co-production activity, we qualitatively determined what types and levels of collective investment were mobilised for collective capabilities using interview materials (see Table 1 and Supplementary Materials 3). For types of collective investment, we followed Ostrom's typology for social capital, distinguishing actors' networks (formal and informal interactions), shared norms (e.g. trust, reciprocity), social beliefs and knowledge (held values), conventions (replicating prior individual decisions), collective rule systems (institutionalised rule sets) and family structure (e.g. family lineage and composition) (Ostrom 1999). We note that a clear differentiation between types remains difficult and might be contextual.

The levels of collective investment for collective capabilities refer to the existence of coordination and frequent interactions between actors, about goals, management practices and rules associated to the Beaufort production system. The sharing of common pool resources (communal pastures, irrigation network...) requires more social coordination of individual objectives and practices between involved actors than the choice of agricultural practices implemented on individual farms (fertilisation levels, crop rotation...) (Ostrom 1990). Therefore, we distinguished between three levels of collective investment: low, medium and high. Although actors, for instance farmers, are embedded in a collaborative system ruled by a set of norms, they can autonomously set their own goals and decide their agricultural practices (e.g. decreasing herd size in winter due to limiting infrastructure). Those activities can be implemented with low levels of collective investment. Actors do not necessarily share the same 
Table 1 Description of co-production activities observed for Beaufort production. Three levels of collective investment are distinguished: low collective investment (i.e. each actor can independently decide of their goals and activities without any coordination with other actors), medium collective investment (i.e. actors pursue different goals, but need to coordinate on the activities they implement to reach them) and high collective investment (i.e. actors pursue the same goals and therefore coordinate to reach them together)

\begin{tabular}{|c|c|c|c|c|c|}
\hline $\begin{array}{l}\text { NCP co-production activi- } \\
\text { ties }\end{array}$ & Description & $\begin{array}{l}\text { No. of } \\
\text { quotes }\end{array}$ & $\begin{array}{l}\text { Types of social capital } \\
\text { involved }\end{array}$ & $\begin{array}{l}\text { Levels of } \\
\text { collective } \\
\text { invest- } \\
\text { ment }\end{array}$ & Example citations \\
\hline
\end{tabular}

\begin{tabular}{|c|c|c|c|c|c|c|}
\hline \multirow[t]{4}{*}{$\begin{array}{l}\text { CP1- } \\
\text { fodder } \\
\text { produc- } \\
\text { tion }\end{array}$} & $\begin{array}{l}\text { Modifying } \\
\text { the share } \\
\text { of regional } \\
\text { fodder }\end{array}$ & $\begin{array}{l}\text { Current Beaufort PDO } \\
\text { requires a minimum of } \\
75 \% \text { of regional fodder. } \\
\text { Some actors suggested } \\
\text { to maintain, soften or } \\
\text { increase this value }\end{array}$ & $\begin{array}{l}\text { WB: } 8 \\
\text { OB: } 10\end{array}$ & $\begin{array}{l}\text { Collective rule system } \\
\text { (PDO certification) }\end{array}$ & High & $\begin{array}{l}\text { "We made some temporary excep- } \\
\text { tions regarding the share of } \\
\text { regional fodder a few years ago. } \\
\text { But, at the moment, we don't ask } \\
\text { ourselves to ease that require- } \\
\text { ment, there is too much behind it." } \\
\text { (Int. 11, employee, WP, 07/2019) }\end{array}$ \\
\hline & $\begin{array}{l}\text { Land expan- } \\
\text { sion }\end{array}$ & $\begin{array}{l}\text { Actors' different strate- } \\
\text { gies to fight land frag- } \\
\text { mentation. It includes } \\
\text { land acquisition, land } \\
\text { exchange and the col- } \\
\text { laborative management } \\
\text { of pastures through land } \\
\text { pastoral associations }\end{array}$ & $\begin{array}{l}\text { WB: } 87 \\
\text { OB: } 84\end{array}$ & $\begin{array}{l}\text { Family structure, } \\
\text { networks, conven- } \\
\text { tion (land contracts, } \\
\text { regulations and land } \\
\text { consolidation) }\end{array}$ & Medium & $\begin{array}{l}\text { "Is it better to make housing for } 50 \\
\text { people in the village or better to } \\
\text { keep the farmer? That's often the } \\
\text { question." (Int. 22, state official, } \\
\text { OB, 07/2019) }\end{array}$ \\
\hline & $\begin{array}{l}\text { Improving } \\
\text { technologi- } \\
\text { cal equip- } \\
\text { ment }\end{array}$ & $\begin{array}{l}\text { Irrigation systems, } \\
\text { additional seeding or } \\
\text { machinery }\end{array}$ & $\begin{array}{l}\text { WB: } 50 \\
\text { OB: } 40\end{array}$ & $\begin{array}{l}\text { Networks, convention } \\
\text { (agreeing over land, } \\
\text { timing and type of irri- } \\
\text { gation system across } \\
\text { actors' groups) }\end{array}$ & Medium & $\begin{array}{l}\text { "Irrigation is important for the } \\
\text { Beaufort zone. There is a real } \\
\text { economy behind these hectares." } \\
\text { (Int. 7, state official, OB, 7/2019) }\end{array}$ \\
\hline & $\begin{array}{l}\text { Managing } \\
\text { the crop } \\
\text { calendar }\end{array}$ & $\begin{array}{l}\text { Agricultural practices } \\
\text { implemented on farm: } \\
\text { harvest dates, grazing } \\
\text { duration, permanent or } \\
\text { temporary herd size }\end{array}$ & $\begin{array}{l}\text { WB: } 50 \\
\text { OB: } 18\end{array}$ & $\begin{array}{l}\text { Family structure, social } \\
\text { beliefs and knowledge } \\
\text { (habits, traditions and } \\
\text { exchange over experi- } \\
\text { ence and knowledge) }\end{array}$ & Low & $\begin{array}{l}\text { "I stay less time in the mountains, I } \\
\text { return end of September and cows } \\
\text { graze on the bottom of the valley. } \\
\text { If they stay up there, they give } \\
\text { less milk." (Int. 23, farmer, WB, } \\
\text { 08/2019) }\end{array}$ \\
\hline \multirow{4}{*}{$\begin{array}{l}\mathrm{CP} 2- \\
\text { milk } \\
\text { transfer } \\
\text { from } \\
\text { farm to } \\
\text { coop- } \\
\text { erative } \\
\text { level }\end{array}$} & $\begin{array}{l}\text { Local cattle } \\
\text { breeds }\end{array}$ & $\begin{array}{l}\text { Beaufort PDO currently } \\
\text { allows only two breeds } \\
\text { (Tarine and Abondance) } \\
\text { for milk production }\end{array}$ & $\begin{array}{l}\text { WB: } 40 \\
\text { OB: } 6\end{array}$ & $\begin{array}{l}\text { Collective rule system } \\
\text { (PDO certification) }\end{array}$ & High & $\begin{array}{l}\text { "But what is behind the colour of a } \\
\text { cow is a real fight over a produc- } \\
\text { tion system." (Int. 11, employee, } \\
\text { WB, 07/2019) }\end{array}$ \\
\hline & $\begin{array}{l}\text { Improving } \\
\text { milk quality }\end{array}$ & $\begin{array}{l}\text { Milk quality is frequently } \\
\text { controlled by coopera- } \\
\text { tives. Beaufort PDO and } \\
\text { national. regulations } \\
\text { define quality rules }\end{array}$ & $\begin{array}{l}\text { WB: } 55 \\
\text { OB: } 1\end{array}$ & $\begin{array}{r}\text { Collective rule system } \\
\text { (PDO specifications) }\end{array}$ & Medium & $\begin{array}{l}\text { "After changing all the farm system, } \\
\text { last year the cooperative told me } \\
\text { that I'm the cleanest producer } \\
\text { regarding the milk proteins. How } \\
\text { was I proud!" (Int. 14, farmer, } \\
\text { WB, 02/2019) }\end{array}$ \\
\hline & $\begin{array}{l}\text { Increasing } \\
\text { milk quan- } \\
\text { tity }\end{array}$ & $\begin{array}{l}\text { Milk quantity produced } \\
\text { on farm is restricted by } \\
\text { a quota system, often } \\
\text { contested by actors. The } \\
\text { variability of milk pro- } \\
\text { duction during the year } \\
\text { is difficult for coopera- } \\
\text { tives to manage (milk } \\
\text { shortages) }\end{array}$ & $\begin{array}{l}\text { WB: } 67 \\
\text { OB: } 2\end{array}$ & $\begin{array}{l}\text { Family structure, social } \\
\text { beliefs and knowledge, } \\
\text { collective rule system } \\
\text { (maintenance of small } \\
\text { to medium holding } \\
\text { size) }\end{array}$ & Medium & $\begin{array}{l}\text { "There is a real risk of losing quan- } \\
\text { tity; we have producers where } \\
\text { nobody knows if somebody will } \\
\text { take the farm after them." (Int. 39, } \\
\text { employee, WB, 08/2019) }\end{array}$ \\
\hline & $\begin{array}{l}\text { Transporting } \\
\text { milk from } \\
\text { farm to } \\
\text { cooperative }\end{array}$ & $\begin{array}{l}\text { Cooperatives collect } \\
\text { milk daily from the } \\
\text { individual farms }\end{array}$ & $\begin{array}{l}\text { WB: } 13 \\
\text { OB: } 20\end{array}$ & $\begin{array}{l}\text { Norms, networks } \\
\text { (government institu- } \\
\text { tions provide road } \\
\text { infrastructure) }\end{array}$ & Medium & $\begin{array}{l}\text { "It's important for the farmers that } \\
\text { we open up the mountaint passes } \\
\text { in spring so that they can access } \\
\text { their pasture land." (Int.40, state } \\
\text { official, OB, 08/2019) }\end{array}$ \\
\hline
\end{tabular}


Table 1 (continued)

\begin{tabular}{|c|c|c|c|c|c|c|}
\hline \multicolumn{2}{|c|}{$\begin{array}{l}\text { NCP co-production activi- } \\
\text { ties }\end{array}$} & \multirow{2}{*}{$\begin{array}{l}\text { Description } \\
\begin{array}{c}\text { Economic benefits and } \\
\text { quality of life generated } \\
\text { by Beaufort production }\end{array}\end{array}$} & \multirow{2}{*}{$\begin{array}{l}\text { No. of } \\
\text { quotes } \\
\text { WB: } 74 \\
\text { OB: } 37\end{array}$} & \multirow{2}{*}{$\begin{array}{l}\text { Types of social capital } \\
\text { involved } \\
\text { Social beliefs and } \\
\text { knowledge, family } \\
\text { structure (attitudes } \\
\text { towards farming pro- } \\
\text { fession) }\end{array}$} & \multirow{2}{*}{$\begin{array}{l}\begin{array}{l}\text { Levels of } \\
\text { collective } \\
\text { invest- } \\
\text { ment }\end{array} \\
\text { High }\end{array}$} & \multirow{2}{*}{$\begin{array}{l}\text { Example citations } \\
\text { "Here, if there wouldn't be the } \\
\text { Beaufort, there would be no } \\
\text { agriculture here." (Int. 1, farmer, } \\
\text { WB, 07/2019) }\end{array}$} \\
\hline $\begin{array}{l}\mathrm{CP} 3- \\
\text { product } \\
\text { sale }\end{array}$ & $\begin{array}{l}\text { Socioeco- } \\
\text { nomic liveli- } \\
\text { hood }\end{array}$ & & & & & \\
\hline & $\begin{array}{l}\text { Landscape } \\
\text { appearance }\end{array}$ & $\begin{array}{l}\text { The Beaufort production } \\
\text { maintains by extensive } \\
\text { grazing activities the } \\
\text { cultural landscape }\end{array}$ & $\begin{array}{l}\text { WB: } 16 \\
\text { OB: } 27\end{array}$ & $\begin{array}{l}\text { Networks, social beliefs } \\
\text { and norms (consensus } \\
\text { over landscape appear- } \\
\text { ance) }\end{array}$ & Medium & $\begin{array}{l}\text { "That's an important aspect. The } \\
\text { maintenance of space. Because if } \\
\text { agriculture stops tomorrow, the } \\
\text { vegetation, the landscape will } \\
\text { deteriorate. For that agricul- } \\
\text { ture needs sto stay." ( Int. 25, } \\
\text { employee, OB, 03/2019) }\end{array}$ \\
\hline & $\begin{array}{l}\text { Personal satis- } \\
\text { faction }\end{array}$ & $\begin{array}{l}\text { Actors' subjective feel- } \\
\text { ings about Beaufort } \\
\text { production and Alpine } \\
\text { agricultural systems }\end{array}$ & $\begin{array}{l}\text { WB: } 125 \\
\text { OB: } 47\end{array}$ & $\begin{array}{l}\text { Social beliefs and } \\
\text { knowledge, family } \\
\text { structure (recognition } \\
\text { from other actors) }\end{array}$ & Low & $\begin{array}{l}\text { "It's more a passion and less a } \\
\text { work." (Int. 26, WB, farmer, } \\
08 / 2019)\end{array}$ \\
\hline & $\begin{array}{l}\text { Work-life bal- } \\
\text { ance }\end{array}$ & $\begin{array}{l}\text { The ratio between leisure } \\
\text { and working time }\end{array}$ & $\begin{array}{l}\text { WB: } 66 \\
\text { OB: } 11\end{array}$ & $\begin{array}{l}\text { Social beliefs and } \\
\text { knowledge, family } \\
\text { structure }\end{array}$ & Low & $\begin{array}{l}\text { "I also want to see my daughter. } \\
\text { Sometimes she asks me when I } \\
\text { will sell the cows." (Int. 14, WB, } \\
\text { farmer, 02/2019) }\end{array}$ \\
\hline
\end{tabular}

goals, nor implement identical activities: duration of grazing period, herd size, accessibility, grass harvesting or time resources can differ across farms. These individual farmer decisions only marginally affect the Beaufort production system. In contrast, some activities require actors to coordinate and agree on the management and the associated rules for the social-ecological system, for instance deciding the use of common lands. These medium levels of collective investment correspond to situations where actors collectively agree on rules over the use or management, but with possible different goals that do not affect the logic of the Beaufort production chain. For instance, farmers can be involved in the same collective irrigation systems, while pursuing different objectives (e.g. supplementary hay for winter fodder vs. increase total livestock). Finally, high levels of collective investment correspond to activities where actors share the same goals and agree on the activities and rules to implement. If actors would modify this co-production activity (e.g. change the type of cattle allowed in Beaufort production), then entire Beaufort production chain would be impacted.

\section{Analysing perceptions and associated sentiments about Beaufort co-production}

In a second step, we analysed the associated sentiments expressed by actors about different co-production activities. Sentiment analysis is widely used for marketing or communication purposes (Twitter, customer-related review sites), but less commonly for qualitative interview data (Liu and Zhang 2012; Lee et al. 2020). In socialecological research, it has been applied to measure placebased perceptions of non-material NCP (Jones et al. 2020). We used sentiment analysis to test whether actors share similar positive or negative sentiments about Beaufort coproduction activities. We used a four-level Likert scale (very positive, moderately positive, moderately negative, very negative) to code and systemize interviewees' overall feeling associated to each of the identified activities. Sentiments were coded manually using the NVivo node system, considering the whole sentence and the general context of the discussion with the interviewee (Neuendorf and Skalski 2009; Liu and Zhang 2012). Very positive sentiments corresponded to sentences where interviewees used highly sentiment-loaded words like "admire" and "love", and very negative sentiments to sentences with overall negative words like "struggle" or "difficult". Moderately positive and moderately negative categories corresponded to less obvious negative or positive meaning. Sentiments were not coded for each specific co-production activity, but for broad sets at each step (CP1, CP2 and CP3) of coproduction (twelve in total). They encompass, for example categories like technology, transport and work-life balance (see Table 1 and refer to Supplementary Materials 3 for the detailed list).

Finally, we analysed the links between collective capabilities and sentiments to identify if activities associated with 
high levels of collective investment are perceived differently in the two actors' groups.

\section{Content analysis for detecting local identities}

Content analysis is a research technique to identify and systemize intentions, themes, trends in texts like online media, journals or transcribed interviews (Gheyle and Jacobs 2017). Content analysis has been used extensively to reveal collective notions like understanding, perceptions and identity in diverse contexts especially in the field of political science (Neuendorf and Skalski 2009). In social-ecological research, content analysis has been widely applied to analyse the evolution of the discipline (Stojanovic et al. 2016), social and environmental disclosures of organisations in social and environmental reporting (Vourvachis and Woodward 2015) and visual and textual representation of ecosystem services in social media (Weber et al. 2017; Oteros-Rozas et al. 2018). Further, content analysis has been applied to understand perceptions of NCP in relation to agricultural practices at regional scale (Bernués et al. 2016).

To implement content analysis, first, we used NVivo builtin tool for word frequency analysis to identify the most frequently mentioned nouns (called "terms" in the following) across all interviews and separately within each group of actors (Jones et al. 2020). We hence identified the most frequent terms separately for each group and checked common terms. We first treated plural and singular forms separate as synonyms and totalled them in a second step for the most frequent terms. We limited our selection to the 16 most frequent terms in each group as the following less frequent terms were overall synonymous or related to the top 16 (Supplementary Materials 4); this kept the number of selected terms tractable for the next step of the analysis (manual sentiment analysis). We grouped these terms into three categories: institutions, place and resources. These are fundamental components on studies on collaborative structures in natural resource management (Ostrom 1990) and were used in other studies on collaborative structures (Pelenc and Ballet 2015). Terms not falling in these categories were grouped in an "other" category.

Secondly, for each term, we conducted a sentiment analysis, following the same approach as for the sentiment analysis described in the previous section (i.e. we used the same fourlevel Likert scale and the same detection criteria for coding sentiment levels).

Finally, we identified the underlying themes related to the most frequent terms, one for each of the three categories (place, institution, resources). These corresponded to the major topics of interviews, which interviewees repeatedly mentioned and therefore constituted a relevant part of their perceptions of the Beaufort production system.

\section{Comparing content and sentiment between actors' groups}

We analysed whether term frequencies and sentiment levels varied between the two groups of actors (WB group vs. OB group) using Student $t$-tests and standardised residual analysis (Agresti 2007). More precisely, we tested (1) the effect of actors' group on each word frequency and sentiment levels (Student $t$-test) and (2) the effect of actors' group on the sentiment levels expressed for each term (residual analysis).

Standardised residuals describe the difference between expected (if there was no pattern of association between actors' group, terms and associated sentiment levels) and observed frequencies in contingency tables. As they follow a standard normal distribution (mean $=0$, standard deviation $=1$ ), residuals with an absolute value that exceeds 2 or 3 mean that there is a significant statistical association between the variables (i.e. residuals are greater than we would expect if the variables were truly independent). In contrast, residuals with values close to zero mean that there is no association. The sign of the residuals describes the nature of the association (positive or negative) (Agresti 2007). Standardised residuals were represented as mosaic graphs (Meyer et al. 2006). The mosaic plot was drawn with the $v c d$ package and $\mathrm{R}$ version 4.0.2 (Meyer et al. 2006, 2020; Zeileis et al. 2007; R Core Team 2020). All graphs were created with $\mathrm{R}$, and the tidyverse (Wickham et al. 2019), ggpubr (Kassambara 2020a), rstatix (Kassambara 2020b) and viridis (Garnier 2018) packages.

\section{Results}

\section{Beaufort co-production activities}

A total of twelve co-production activities were identified along the Beaufort production chain in the interviews, for a total of 974 quotes (Table 1 and SM 3). In the first step (CP1), representing fodder production, actors mentioned four types of activities: modifying the share of regional fodder (to comply with the $75 \%$ specification), improving the technological equipment (irrigation, machinery...), increasing land extension (exchanges, purchases...) and managing the crop calendar and the main agricultural practices on the farm (harvest date, herd size...). CP2 considers the mobilisation of ecological resources, e.g. only milk from the two regional cattle breeds (which we consider as an ecological resource) is legitimate for the production of Beaufort cheese. In CP2, actors cited as activities: regional cattle breeds (Tarine and Abondance), increasing milk quantity, improving milk quality (protein and fat levels, hygiene indicators) and transporting the milk to the cooperative. In CP3 (product sale), actors listed socioeconomic livelihood, landscape appearance, personal satisfaction and work-life balance as main elements. 
Co-production activities related to personal satisfaction (CP3) received the highest number of quotes, then followed by land expansion (CP1) (Table 1). The number of quotes each activity received during the interviews varied across actors' groups: actors involved directly in the Beaufort chain (WB group) mentioned much more activities related to the translation of agricultural activities to a final NCP benefit (CP3) than other actors (Table 1). This highlights the importance of Beaufort production for their good quality of life.

\section{Collective capabilities surrounding Beaufort co-production}

Co-production activities required different types of collective social capital, listed in Table 1, and that we further classified into three levels of collective investment (low, medium and high), depending on the social coordination of individual objectives and practices between involved actors for Beaufort co-production.

The types and levels of collective investment of social capital mobilised for the NCP co-production varied along the co-production cascade (Table 1). For CP1, crop calendar management was an individual decision, reflecting each farmer's preferences and possibilities and less interactions with other actors (low levels of collective investment): this involved only social beliefs and knowledge and household structure. Improving the technological equipment and increasing land extension received the highest number of quotes in both groups. This activity required the actors to coordinate at some point, across or within the two groups, using conventions and actors' networks (medium levels of collective investment), as illustrated by this quote:

“[About land exchange] They don't necessarily like each other, everyone does things differently, but still they work together on that." (Int. 1, farmer, 07/2019).

The easing or tightening of the $75 \%$ regional fodder requirement required high levels of collective investment. This rule is part of a set of PDO specifications (i.e. a collective rule set) that shapes the entire production system. Actors from the OB group are less involved in this activity and quoted them accordingly less. However, it was subject to many discussions for actors from the WB group:

"We need to evaluate the restrictions for Beaufort for all farms. But, for sure we must not change them, it's on us to adapt." (Int. 36, farmer, WB, 08/2019)

Activities in CP2 were mainly cited by the WB group and less by the OB group, suggesting that the latter are less involved at this step of co-production (Table 1). Activities related to increasing milk quantity, improving quality (both mobilised collective rules) and transporting milk from farm to cooperative level (norms, networks) required medium levels of collective investment. They corresponded to each farmer's individual objectives and strategies to have a viable business while complying with PDO specifications, national regulations (hygiene, milk storage) and the individual cooperatives' habits for transport. The restriction to local cow breeds (also based on collective rules) relies on high levels of collective investment as the restriction to low yielding cattle implies extensive farming, a strong symbol for the Beaufort cheese. Any modification would entail fundamental changes in the current production, as expressed in this quote:

"If you want another cattle breed that produces more, it's because of its genes, but then the hay is not sufficient, it needs more grains. And then you lose the link with the region." (Int. 02, employee, WB, 07/2019).

At CP3, activities were more frequently mentioned by actors from the WB group (Table 1 and SM 3/Table 2). As personal satisfaction and work-life balance can be considered as individual choices which depend on individual appreciation, most of the social capital mobilised (i.e. social beliefs and family structure) corresponded to low collective investment, except landscape appearance (medium levels of collective investment) and socioeconomic livelihood (high levels of collective investment) which rather mobilised networks and collective rules. Overall, the PDO specifications (controlling livestock breed, milk quantity at CP2 and forage origin at CP1) effectively limit the farm size and set as a rule small-scale traditional farming systems. The specifications also provide a financial security as farmers can sell their milk to Beaufort cooperatives at almost double the market price. This is illustrated by the following quote:

"Thanks to the cooperative I have money on my bank account." (Int. 23, farmer, WB, 08/2019)

\section{Sentiments about Beaufort co-production activities}

In general, co-production activities were described with positive sentiments by the two groups (very or moderately positive levels represented more than $65 \%$ in both groups), except milk quantity, land extension and work-life balance which received higher levels of negative sentiments (Fig. 3).

In the WB group, activities receiving the highest share of positive sentiments were local breeds (CP2) and landscape appearance (CP3). In the OB group, the best perceived activities were milk quality and transport, and landscape appearance (Fig. 3). These activities are tightly related to the Beaufort PDO and require high cooperation and interactions between actors (medium to high levels of collective investment). This suggests that the Beaufort 
Fig. 3 Sentiment analysis for activities at the three steps of nature's contributions to people co-production. Each nature's contributions to people co-production activity is associated with a level of collective investment $(+=$ low,$++=$ med ium, $+++=$ high)

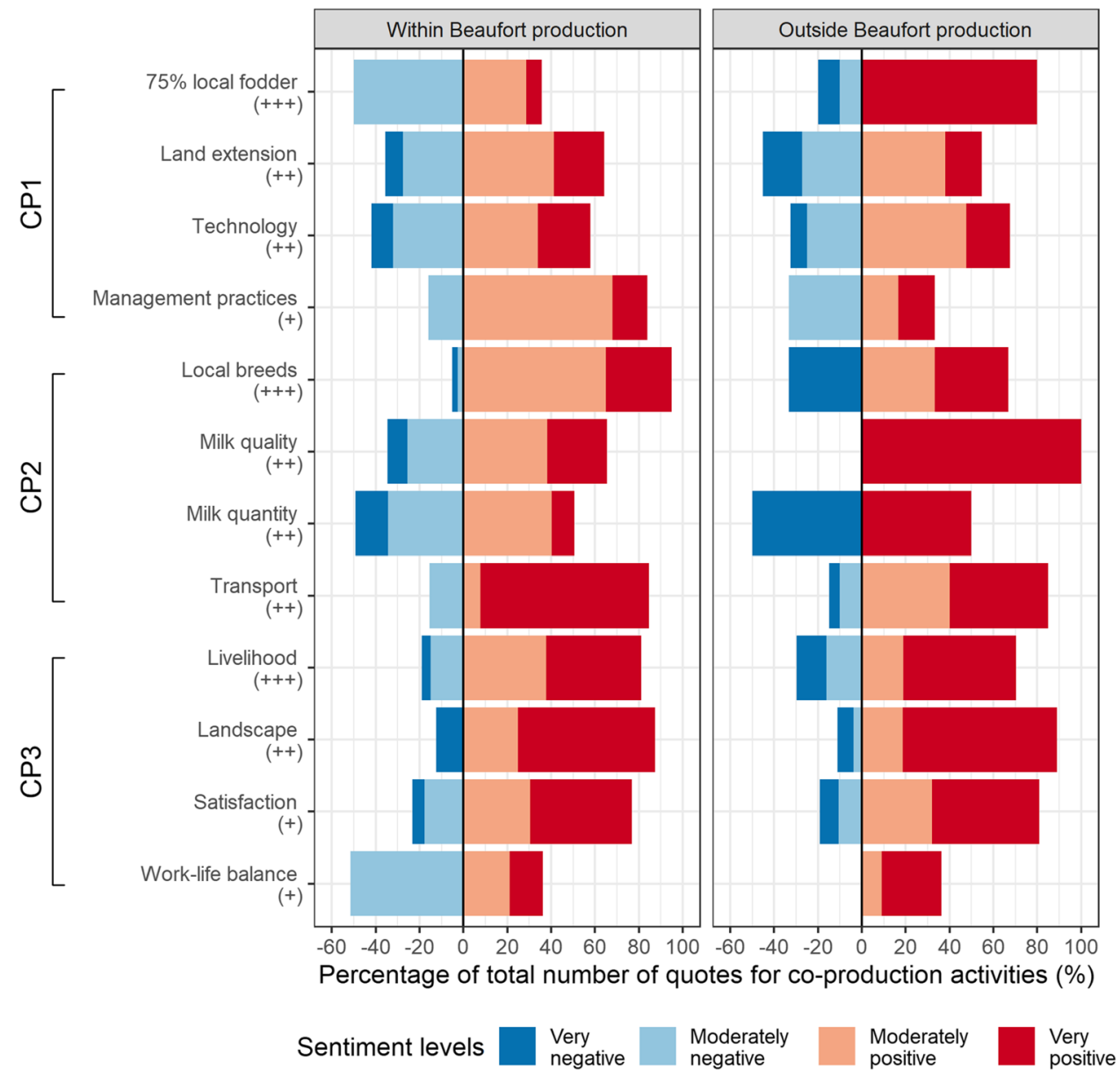

PDO is not seen as a constraint, but as an opportunity that contributes to sustain local agriculture. The milk quotas (milk quantity) imposed by the PDO received mixed sentiments: some actors said it prevented them from increasing production, which might become a problem in the future if milk production does not keep up with the demand for Beaufort cheese. But others also indicated that the quota system keeps milk production aligned with available land, environmental constraints, infrastructure and workforce, which was positively perceived.

"For doing agriculture in the mountains, first you need to love mountains, second you need to love agriculture, this means you need to love constraints." (Int. 36, farmer, WB, 08/2019)

We did not detect any significant association between the type of social capital mobilised by different levels of collective investment co-producing NCP and the associated sentiments. This suggests that perceptions about co-production depend more on the nature of the activity and its contributions to good quality of life than on the specific social capitals mobilised.

\section{Highlighting local identities with terms frequency analysis}

Among the 16 most frequent terms analysed in each group, twelve were common to both (Fig. 4B and C), suggesting a common understanding and perception of local identities associated to Maurienne agricultural landscapes. These terms were "land", "Maurienne", "mountain" and "summer pasture" in the place category; "cow" and "time" in the resources category and "Beaufort" (this word is often used to describe the organisational structure, rarely the cheese product), "council of municipalities", "municipality" and "pastoral land association" in the institutions category. The terms "project" and "people" were too general to specifically belong to any of these categories and were merged as "other". Few terms were specific to each group; they were mainly related to cattle farming in $\mathrm{WB}$ and to tourism in $\mathrm{OB}$ (Fig. 4B and C). A list of total quotes of terms for each sentiment level is provided in Supplementary Materials 4, Fig. 1, a qualitative description of the 16 most frequent terms of both groups in Supplementary Materials 5 and significance tests in Supplementary Material 6. 
Fig. 4 A The relative distribution of quotes in each group and total. $\mathbf{B}$ and $\mathbf{C}$ Mosaic plot of the frequency of the sentiment analysis of the 16 most frequent terms for the two different groups of actors (B WB group, $\mathrm{C} \mathrm{OB})$. Each box is associated with a term in the left list and a Likert scale level on the top $(++=$ very positive, $+=$ moderately positive, $-=$ moderately negative, $--=$ very negative). The height of a box is proportional to the word counts. The width of a box is proportional to the number of counts at each level of the Likert scale, for the two groups of actor separately. Box colour highlights cells which are individually significant at approximately $\alpha=0.05, \alpha=0.01$ and $\alpha=0.001$ levels, respectively. Blue boxes indicate positive residuals (i.e. it is more likely that an actor of a group mentions a term with a given sentiment level than expected if the variables were independent), and red boxes indicate negative residuals. For sake of simplicity, boxes with absolute residuals below the critical value of $95 \%$ are white.

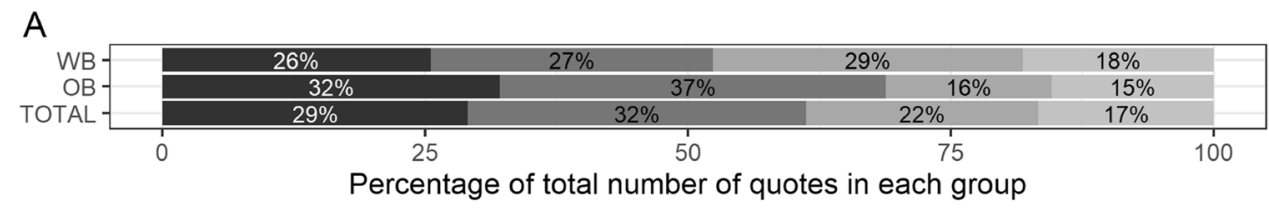

Category of words $\square$ Place $\amalg$ Institutions $\quad$ Resources $\quad$ Other

B

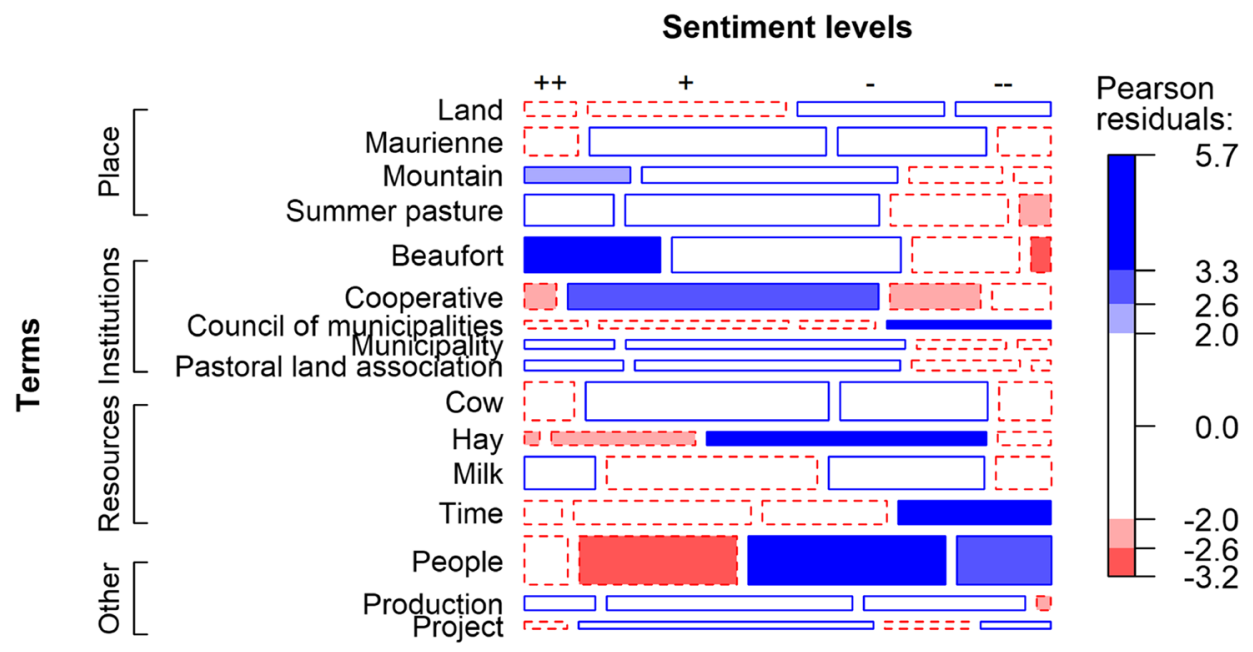

C

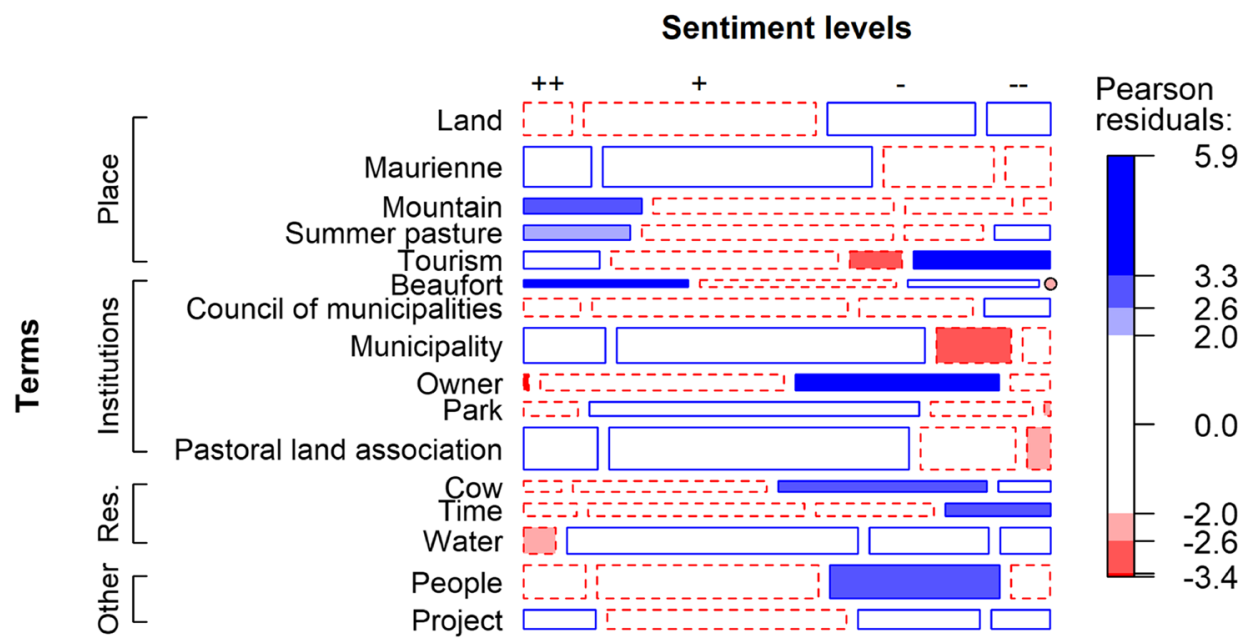

We identified 4134 quotes including at least one of the 20 frequent terms mentioned in the two groups. Terms referring to institutions were the most frequent (32\% total quotes), followed by place (29\%) and resources (22\%) (Fig. 4A). Interestingly, resources terms represented $29 \%$ of WB quotes, while it concerned only $16 \%$ of OB group. This underlines the relevance of the key resources cattle and time for agricultural activities. Both groups similarly referred to place terms, indicating agreement on the importance of the mountain environment for the
Beaufort agricultural system and the construction of local identities.

\section{Sentiments differences between groups}

WB actors quoted resource terms "cow" and "time" significantly more than OB actors (Fig. 4B and C). Notably, WB actors used the term "time" with significantly more negative sentiments. This is because time was often referred to as limiting production, but also life quality. It echoes the previous 
observation from the analysis of co-production activities, where we observed that work-life balance was more often mentioned with negative sentiments. As an actor exclaimed:

"Today the farmer works every day. He doesn't have the time to go to any festivities. And that's also really important." (Int. 01, farmer, WB, 07/2019)

WB actors also used "summer pasture" and "Beaufort" with significantly more positive sentiments. OB actors quoted "Beaufort" less frequently, but with more positive sentiments. This highlights the importance of the mountain environment and Beaufort PDO in the sense of place and local identities of the Maurienne valley, as illustrated by the following citations:

"Without Beaufort, without that decision, without this choice, agriculture in the mountains would have disappeared." (Int. 1, farmer, WB, 07/2019)

"Beaufort has really saved the agriculture here. Without Beaufort there would be no agriculture here." (Int. 22, state official, OB, 07/2019)

WB actors referred significantly less than expected to institution terms "pastoral land association" and "municipality", while OB actors used them more frequently, with positive sentiments only (Fig. 4B, C, SM 6). This suggests that actors might have diverging views and opinions on the institutions facilitating agricultural activities in Maurienne, with WB actors praising the cooperative systems, while OB actors favoured public institutions. This is not surprising given our prior definition of the groups.

WB actors used the term "land" with significantly less positive sentiments, and OB actors with significantly more negative sentiments (Fig. 4), which reflects strong land competition, including with tourism:

"What kind of mountains do we want? A protected mountain, one for sport, one for only agriculture, an empty one? We have to talk about this." (Int. 7, state official, OB, 07/2019)

\section{Discussion}

\section{Collective capabilities contributions to nature's contributions to people co-production}

Our results highlight the importance of several collective capabilities supporting Beaufort production. We found that most activities which structure, organise and maintain Beaufort production, including the $75 \%$ local fodder requirement and the restriction to local cattle breeds, rely on high levels of collective investment. The positive sentiments of both actors' groups regarding these activities highlight the importance of shared views across heterogeneous actors in regional production systems. This indicates that actors inside and outside these systems are aware of the collective capabilities, thus the benefits they retrieve from this type of social-ecological interaction. It highlights that these benefits surpass pure economic considerations that benefit a wide range of actors. In addition, the Beaufort system depends on activities that require low and medium levels of collective investment. Interestingly, we did not find any congruent pattern between the levels of collective investment and the types of mobilised social capital. This suggests that collective capabilities depend on current formal or informal institutions and less on pre-existing social capital. For future research, we suggest to extend research on social capital by integrating social network analysis (Pachaud et al., 2020). This could evaluate the relevance of the qualitative and quantitative strength of relations between individual actors on collective capabilities. Other studies similarly observed that collective structures are essential for the co-production of NCP and the maintenance of small-scale mountain farming systems, in the French Alps (Lamarque and Lambin 2015), the Italian Alps (Pachoud et al. 2020) or Austria and Norway (Schermer et al. 2016). Some results of our interviews also suggest that actors' individual agency and resources were crucial in the production and the functioning of relevant collective capabilities. For instance, some individuals played a crucial role in mobilising social capital (e.g. by meeting actors across scales and professions) during the creation of the Beaufort cooperative system in the 1960s (Dubeuf 1996; Faure 1999; Lynch and Harvois 2016). This supports the idea that collective capabilities result from social interactions coupled with individual agency (Ballet et al. 2007). To better address these interlinkages between collective capabilities and agency, future research needs to investigate enabling conditions at individual level and regarding actors' organisation within society enabling the emergence and maintenance of collective capabilities (Sen 2000; Ibrahim 2006). Quantitative methods like social network analysis could support this research (Vallet et al. 2019b; Pachoud et al. 2020).

\section{How does nature's contributions to people co-production via collective capabilities contribute to local identities?}

Our analyses identified the Beaufort PDO as an important collective institution generating collective capabilities that contribute to local identities. This is consistent with previous conclusions that local identity is an incontestable part of the Beaufort production (Dubeuf 1996; Faure 1999; Lynch and Harvois 2016). The regional fodder requirement establishes strong links between livestock numbers and available land, thus effectively preventing large increases of herd sizes. The requirement of regional cattle breeds maintains the cultural 
heritage. Indeed, small-scale milk production for Beaufort cheese appeared central to local identities in Maurienne, as supported by interviewees' frequent mentions of "summer pasture", "cattle" and "Beaufort". Additionally, the differences between the two actors' groups match previous findings on differing perceptions regarding agriculture's contributions to good quality of life depending on their activities and actions in agricultural production (Poppenborg and Koellner 2013). Nevertheless, actors recognised a trade-off between this valued production system and its time intensiveness, which aligns with recurring perceptions in agricultural systems (Lunner Kolstrup et al. 2013; Naik 2017; Annibal et al. 2019).

The overall positive sentiments highlight the positive social representation of the Beaufort cheese. This intrinsic link between Beaufort production and local identities already identified 25 years ago (Dubeuf 1996) appears to have persisted. Cheese production can be a defining element of local identities (Bérard et al. 2008; Dos Santos 2017). Mountain cheese production is linked to the surrounding landscape and traditional farming practices and can thus become a symbol of local identities (Delfosse 2006). European quality schemes like PDO labels, and since 2012 the "mountain products" label, acknowledge the strong cultural identity and tradition of mountain regions (Santini et al. 2013; EC 2020). Similar identity dimensions of quality labels were observed for the Jura region in the French Alps Comté cheese (Dos Santos 2017). The contributions of collective capabilities to local identities has been observed for products with comparable geographical indications labels, like Serrano cheese in Southern Brazil (Pachoud 2019), olive oil in Spanish Andalusia (Sanz Cañada and Macías 2005) or coffee in the mountains of Bali (Fournier 2008). These products can maintain regional identities by sustaining rural economies (Cei et al. 2018) and contribute to local ecosystem protection (Belletti et al. 2015; Lamarque and Lambin 2015; Dos Santos 2017).

\section{Local identities, relational values and contributions to good quality of life}

NCP co-production contributes in multiple ways to a good quality of life (Díaz et al. 2015). The Beaufort production system insures socioeconomic livelihood (CP3). In addition, actors considered other co-production aspects beyond instrumental/ economic benefits. We grouped these non-material aspects of personal satisfaction, landscape appearance and work-life balance (CP3) under the notion of relational values (Pascual et al. 2017; Schröter et al. 2020). Actors quoted different dimensions of personal satisfaction, such as being satisfied with their professions, their working environment or their animal husbandry. In addition, actors appreciated the appearance of their surrounding ecosystem. Relational values can explain the number of quotes for personal satisfaction (172 quotes) against the lower number of quotes and low level of positive sentiments for work-life balance (77 quotes). The importance of relational values can explain the absence of revenue-related terms (e.g. money, capital, income) in the discourses. This is consistent with evidence that economic considerations are accompanied by questions of lifestyle when choosing mountain farming as a profession (Hinojosa et al. 2016; Schermer et al. 2016). These observations also align the capability approach highlighting that people engage in activities not only for the pure maximisation of joy and happiness, but because the process itself aligns with higher goals and contributes to their interpretation of a meaningful life (Alkire 2008; Ballet et al. 2018). In addition, collective capabilities theories argue that social interactions with people who share one's interests contribute to a good quality of life and are central to the development of identities (Evans 2002). Given this multidimensionality of relational values, individuals can appreciate the involvement in collaborative structures for diverse reasons (Rauschmayer et al. 2018). Summed up, our analyses showed how in the Maurienne's Beaufort production system collective capabilities contribute in socioeconomic terms, subjective feelings and social interactions to a good quality of life and facilitate in a wider framing the maintenance of local identities.

\section{Methodological considerations: unravelling the links between nature's contributions to people co-production, collective capabilities and local identities with sentiment analysis}

We evaluated the role of collective capabilities in the different steps of Beaufort cheese co-production in the French Alps from interviews of 43 actors of the Maurienne agricultural system, depending on whether actors were directly involved Beaufort cheese production chain or not. Our mixed method enabled integrating qualitative and quantitative information. Word frequency, commonly used to analyse general themes in interviews or large corpus datasets (Droste, D'Amato, and Goddard 2018), enabled a precise and exhaustive identification of key terms.

Post-interpreting sentiment from in-text context rather than explicitly asking interviewees to express their sentiment about terms and activities is common practice (Lee et al. 2020). Such qualitative information is crucial in sentiment analyses as automated algorithms (e.g. NVivo) attributing predetermined sentiment scores to "sentimentally loaded words" (Jones et al. 2020) do not always correctly reveal people's preferences and value-systems. Although manual coding was in some cases a difficult and time-consuming task, as subtle, less pronounced emotions can be difficult to detect in written datasets, we believe it was more efficient for determining sentiment scores depending on context. This way, some terms received both positive and negative scores, like milk whose production is crucial for Beaufort cheese (and justifies positive sentiments), but whose quota restrictions 
and the associated work load are often seen as constraints by farmers (negative sentiments). However, manual coding limits the transferability of our method to other contexts, as a profound familiarisation with the dataset precedes manual coding. Data mining tools offer promising avenues for future, more sensitive coding of themes for sentiment analysis (Liu and Zhang 2012; Hale et al. 2019; Mascareño et al. 2020).

\section{Conclusion}

Our empirical analysis of the Maurienne's Beaufort cheese production system advanced prior research on linkages between collective capabilities, identities and their contribution to a good quality of life. We shifted the unit of analysis from collective resource management to the entire production chain and focused on the social dimensions of NCP coproduction. The emphasis on the social dimensions of NCP co-production allowed us to unravel the role of social interactions, thus going beyond analyses of flows between society and ecosystems. The collective capability approach appeared particularly useful in conceptualising multidimensional and cross-sectoral benefits of collective action to different dimensions of a good quality of life because it renders the different levels and types of interactions between actors visible. However, aspects of a good quality of life appeared to be more linked to the type of activity than the form of social interaction. Nevertheless, we suggest investigating possible linkages between types of social coordination and their contributing role in social-ecological interactions more thoroughly. Considering the impacts of evolving lifestyles and consumption patterns on regional extensive farming systems, such new approaches are required to understand how people relate to their surrounding environment. This will help developing pathways to maintain these local production systems. Lastly, our approach offers the opportunity to further investigate and operationalise the role of collective structures in social-ecological interactions from a social science perspective.

Supplementary Information The online version contains supplementary material available at https://doi.org/10.1007/s10113-021-01840-9.

Funding This work was supported by the Université Grenoble Alpes Cross-Disciplinary Project Trajectories funded by the French National Research Agency "Investissements d'avenir" programme (ANR-15-IDEX-02).

Open Access This article is licensed under a Creative Commons Attribution 4.0 International License, which permits use, sharing, adaptation, distribution and reproduction in any medium or format, as long as you give appropriate credit to the original author(s) and the source, provide a link to the Creative Commons licence, and indicate if changes were made. The images or other third party material in this article are included in the article's Creative Commons licence, unless indicated otherwise in a credit line to the material. If material is not included in the article's Creative Commons licence and your intended use is not permitted by statutory regulation or exceeds the permitted use, you will need to obtain permission directly from the copyright holder. To view a copy of this licence, visit http://creativecommons.org/licenses/by/4.0/.

\section{References}

Agresti A (2007) An introduction to categorical data analysis. 2nd ed. Hoboken, NJ: Wiley-Interscience (Wiley series in probability and mathematical statistics)

Alkire S (2008) The capability approach to the quality of life. A background paper for the Commission on the Measurement of Economic Performance and Social Progress, instigated by President Sarkozy. Oxford Poverty \& Human Development Initiative. https://ophi.org.uk/ophi-research-paper-2a/. Accessed 07/10/2021

Annibal I, Prize L, Sellick J (2019) Health and wellbeing report. [accessed 2020 Sep 25]. http://eprints.lincoln.ac.uk/id/eprint/ $41180 /$.

Ballet J, Dubois J, Mahieu F (2007) Responsibility for each other's freedom: agency as the source of collective capability. J Hum Dev 8(2):185-201. https://doi.org/10.1080/14649880701371000

Ballet J, Marchand L, Pelenc J, Vos R (2018) Capabilities, identity, aspirations and ecosystem services: an integrated framework. Ecol Econ 147:21-28. https://doi.org/10.1016/j.ecolecon.2017. 12.027

Belletti G, Marescotti A, Sanz-Cañada J, Vakoufaris H (2015) Linking protection of geographical indications to the environment: evidence from the European Union olive-oil sector. Land Use Policy 48:94-106. https://doi.org/10.1016/j.landusepol.2015.05.003

Bennett NJ (2016) Using perceptions as evidence to improve conservation and environmental management: perceptions and conservation. Conserv Biol 30(3):582-592. https://doi.org/10.1111/cobi. 12681

Bérard L, Marchenay P, Voinson J (2008) From localized products to geographical indications - awareness and action. Bourgen-Bresse: CNRS, Ressources des terroirs-Cultures, usages, sociétés

Bernués A, Tello-García E, Rodríguez-Ortega T, Ripoll-Bosch R, Casasús I (2016) Agricultural practices, ecosystem services and sustainability in high nature value farmland: unraveling the perceptions of farmers and nonfarmers. Land Use Policy 59:130-142. https://doi.org/10.1016/j.landusepol.2016.08.033

Bratman GN, Anderson CB, Berman MG, Cochran B, de Vries S et al (2019) Nature and mental health: an ecosystem service perspective. Sci Adv 5(7):eaax0903. https://doi.org/10.1126/ sciadv.aax0903

Bruley E, Locatelli B, Lavorel S (2020) Nature's contributions to people: co-producing quality of life from multifunctional landscapes. Ecol Soc Revis. https://doi.org/10.5751/ ES-12031-260112

Bruley E, Locatelli B, Lavorel S (2021) Nature's contributions to people: coproducing quality of life from multifunctional landscapes. Ecol Soc. 26(1). https://doi.org/10.5751/ES-12031-260112. [accessed 2021 Apr 26]. https://www.ecologyandsociety.org/ vol26/iss1/art12/.

Bruley E, Locatelli B, Vendel F, Bergeret A, Elleaume N et al (2021) Historical reconfigurations of a social-ecological system adapting to economic, policy and climate changes in the French Alps. Reg Environ Change. 21(2). https://doi.org/10.1007/s10113-02101760-8. [accessed 2021 Apr 26]. http://link.springer.com/https:// doi.org/10.1007/s10113-021-01760-8. 
Bryman A (2016) Social research methods. Fifth Edition. Oxford; New York: Oxford University Press.

Buclet N, Donsimoni M (2018) L'écologie territoriale ou comment resituer l'économie au-delà de la sphère monétaire. In: Renouveler la géographie économique,. Magali Talandier, Benard Pecqueur. Economica-Anthropos, Paris

Canada JS, Vazquez AM (2005) Quality certification, institutions and innovation in local agro-food systems: Protected designations oforigin of olive oil in Spain. J Rural Stud 21:475-486. https:// doi.org/10.1016/j.jrurstud.2005.10.001

Cei L, Defrancesco E, Stefani G (2018) From geographical indications to rural development: a review of the economic effects of European Union policy. Sustainability 10(10):3745. https://doi. org/10.3390/su10103745

Comim F, Carey F (2001) Social capital and the capability approach: are Putnam and Sen incompatible bedfellows? Work Pap St Edmund's Coll.

Cook EM, Hall SJ, Larson KL (2012) Residential landscapes as socialecological systems: a synthesis of multi-scalar interactions between people and their home environment. Urban Ecosyst 15(1):19-52. https://doi.org/10.1007/s11252-011-0197-0

Copernicus Land Monitoring Service (2018) Corine Land Cover (CLC) version 2020_20u1. https://land.copernicus.eu/pan-european/ corine-land-cover/clc2018?tab=metadata.

Delfosse C (2006) La localisation de la production fromagère: évolutions des approches géographiques. Géocarrefour 81(4):311-318. https://doi.org/10.4000/geocarrefour.1674

Dendoncker N, Boeraeve F, Crouzat E, Dufrêne M, König A et al (2018) How can integrated valuation of ecosystem services help understanding and steering agroecological transitions? Ecol Soc 23(1). https://doi.org/10.5751/ES-09843-230112. [accessed 2020 Sep 30]. https://www.ecologyandsociety.org/vol23/iss1/art12/.

Díaz S, Demissew S, Carabias J, Joly C, Lonsdale M, Ash N, Larigauderie A, Adhikari JR, Arico S, Báldi A et al (2015) The IPBES conceptual framework - connecting nature and people. Curr Opin Environ Sustain 14:1-16. https://doi.org/10.1016/j.cosust. 2014.11.002

Díaz S, Pascual U, Stenseke M, Martín-López B, Watson RT, Molnár Z, Hill R, Chan KMA, Baste IA, Brauman KA et al (2018) Assessing nature's contributions to people. Science 359(6373):270-272. https://doi.org/10.1126/science.aap8826

Dissart J-C (2012) Co-construction des capacités et des ressources territoriales dans les territoires touristiques de montagne: Étude de cas sur l'Oisans. Rev Géographie Alp.(100-2). https://doi.org/ 10.4000/rga.1781. [accessed 2021 Apr 28]. http://journals.opene dition.org/rga/1781.

Dos Santos A (2017) Labelling mountain food products in Europe beyond the simple quality distinction, an opportunity to join forces and build resilient food systems. [Netherlands]: Wageningen University. [accessed 2020 Sep 24]. https://www.euromontana.org/en/ our-approche/euromontanas-publications/.

Dubeuf B (1996) La construction d'un produit de terroir haut de gamme: le Beaufort. Économie Rurale 232(1):54-61. https://doi.org/10. 3406/ecoru.1996.4784

Droste N, D'Amato D, Goddard JJ (2018) Where communities intermingle, diversity grows \pm The evolution of topics in ecosystem serviceresearch. PLoS ONE 13(9):e0204749. https://doi.org/10. 1371/journal.pone.0204749

EC (2020) Quality schemes explained. [accessed 2020 Sep 23]. https:// ec.europa.eu/info/food-farming-fisheries/food-safety-and-quality/ certification/quality-labels/quality-schemes-explained_en\#other schemes.

Elmi M, Streifeneder TP, Ravazzoli E, Laner P, Petitta M et al (2018) The Alps in 25 Maps. Permanent Secretariat of the Alpine Convention.http://www.alpconv.org/en/publications/alpine/Docum ents/25maps.pdf
Evans P (2002) Collective capabilities, culture, and Amartya Sen's development as freedom. Stud Comp Int Dev 37(2):54-60. https://doi. org/10.1007/BF02686261

Fagerholm N, Martín-López B, Torralba M, Oteros-Rozas E, Lechner AM et al (2020) Perceived contributions of multifunctional landscapes to human well-being: evidence from 13 European sites. Lovell R, editor. People Nat. 2(1) 217-234. https://doi.org/10. 1002/pan3.10067.

Faure M (1999) Un produit agricole «affiné» en objet culturel: Le fromage Beaufort dans les Alpes du Nord. Terrain 33:81-92. https:// doi.org/10.4000/terrain. 2703

Fedele G, Locatelli B, Djoudi H (2017) Mechanisms mediating the contribution of ecosystem services to human well-being and resilience. Ecosyst Serv 28:43-54. https://doi.org/10.1016/j. ecoser.2017.09.011

Filippi M, Torre A (2003) L'organisation en réseau: de l'instauration de règles locales aux actions collectives. In: Entreprises et territoires; les nouveaux enjeux de la proximité. La Documentation française. Dupuy Claude, Burmeister Antje.

Fischer A, Eastwood A (2016) Coproduction of ecosystem services as human-nature interactions-an analytical framework. Land Use Policy 52:41-50. https://doi.org/10.1016/j.landusepol.2015. 12.004

Forster J, Turner RA, Fitzsimmons C, Peterson AM, Mahon R et al (2017) Evidence of a common understanding of proximate and distal drivers of reef health. Mar Policy 84:263-272. https://doi. org/10.1016/j.marpol.2017.07.017

Forsyth T (2015) Ecological Functions and Functionings: towards a Senian Analysis of Ecosystem Services. Dev Change 46(2):225246. https://doi.org/10.1111/dech.12154

Fournier S (2008) Les Indications géographiques: une voie de pérennisation des processus d'action collective au sein des Systèmes agroalimentair. Cah Agric 17(6):547-551. https://doi.org/10.1684/ agr.2008.0250

Frey JB, Berkes F (2014) Can partnerships and community-based conservation reverse the decline of coral reef social-ecological systems? Int J Commons 8(1):26. https://doi.org/10.18352/ijc.408

Garnier S (2018) viridis: default color maps from "matplotlib”. R package version 0.5.1. https://CRAN.R-project.org/package= viridis. https://CRAN.R-project.org/package=viridis. Accessed May 31 2021

Gheyle N, Jacobs T (2017) Content analysis: a short overview. Intern Res Note.

Grosinger J, Potts MD, Buclet N, Lavorel S (in review) Memory over matter? - a conceptual framework to integrate social-ecological legacies in agricultural NCP co-production. Sustain Sci (in revision)

Hale RL, Cook EM, Beltrán BJ (2019) Cultural ecosystem services provided by rivers across diverse social-ecological landscapes: a social media analysis. Ecol Indic 107:105580. https://doi.org/10. 1016/j.ecolind.2019.105580

Herzog LM, Ingold K (2019) Threats to common-pool resources and the importance of forums: on the emergence of cooperation in CPR problem settings. Policy Stud J 47(1):77-113. https://doi.org/10. $1111 /$ psj. 12308

Hinojosa L, Napoléone C, Moulery M, Lambin EF (2016) The "mountain effect" in the abandonment of grasslands: insights from the French Southern Alps. Agric Ecosyst Environ 221:115-124. https://doi.org/10.1016/j.agee.2016.01.032

Ibrahim SS (2006) From individual to collective capabilities: the capability approach as a conceptual framework for self-help. J Hum Dev 7(3):397-416. https://doi.org/10.1080/14649880600815982

IGN-F I national de l'information géographique et forestière (2006) BD Carthage version 3.0. http://www.sandre.eaufrance.fr/sites/defau 1t/files/IMG/pdf/1-DC_BDCARTHAGE_3_0.pdf. 
IGN-F I national de l'information géographique et forestière (2019) BD TOPO® -Base de Données Topographiques. https://geoservices. ign.fr/ressources_documentaires/Espace_documentaire/BASES_ VECTORIELLES/BDTOPO/IGNF_BDTOPOr_3-0.html.

INAO (Institut national de l'origine et de la qualité) (2015) Cahier des charges de l'appellation d'origine «Beaufort»

Jones L, Holland RA, Ball J, Sykes T, Taylor G et al (2020) A placebased participatory mapping approach for assessing cultural ecosystem services in urban green space. Ladle R, editor. People Nat. 2(1):123-137. https://doi.org/10.1002/pan3.10057.

Kassambara A (2020a) ggpubr: "ggplot2" based publication ready plots. $\mathrm{R}$ package version 0.4.0. https://CRAN.R-project.org/package $=$ ggpubr. Accessed 1 June 2021

Kassambara A (2020b) rstatix: pipe-friendly framework for basic statistical tests. R package version 0.6.0. https://CRAN.R-project.org/ package $=$ rstatix. Accessed 1 June 2021

Koohafkan P, Altieri MA (2011) Globally important agricultural heritage systems: a legacy for the future. Food and Agriculture Organization of the United Nations Rome.

Kramer R, Tyler T (1996) Trust in organizations: frontiers of theory and research. SAGE Publications, Inc. [accessed 2021 Apr 28]. http://sk.sagepub.com/books/trust-in-organizations.

Lamarque P, Lambin EF (2015) The effectiveness of marked-based instruments to foster the conservation of extensive land use: the case of geographical indications in the French Alps. Land Use Policy 42:706-717. https://doi.org/10.1016/j.landusepol.2014. 10.009

Leach M, Mearns R, Scoones I (1999) Environmental entitlements: dynamics and institutions in community-based natural resource management. World Dev 27(2):225-247. https://doi.org/10. 1016/S0305-750X(98)00141-7

Lee J, Park H, Kim I, Kwon H (2020) Analysis of cultural ecosystem services using text mining of residents' opinions. Ecol Indic 115:106368. https://doi.org/10.1016/j.ecolind.2020.106368

Lehtonen M (2004) The environmental-social interface of sustainable development: capabilities, social capital, institutions. Ecol Econ 49(2):199-214. https://doi.org/10.1016/j.ecolecon.2004.03.019

Lescourret F, Magda D, Richard G, Adam-Blondon A-F, Bardy M et al (2015) A social-ecological approach to managing multiple agroecosystem services. Curr Opin Environ Sustain 14:68-75. https:// doi.org/10.1016/j.cosust.2015.04.001

Lessmann O, Rauschmayer F (2013) Re-conceptualizing sustainable development on the basis of the capability approach: a model and Its difficulties. J Hum Dev Capab 14(1):95-114. https://doi.org/ 10.1080/19452829.2012.747487

Liu B, Zhang L (2012) A survey of opinion mining and sentiment analysis. In: Aggarwal CC, Zhai C, editors. Mining text data. Boston, MA: Springer US. p. 415-463. [accessed 2020 Aug 26]. http:// link.springer.com/https://doi.org/10.1007/978-1-4614-3223-4_13.

Lunner Kolstrup C, Kallioniemi M, Lundqvist P, Kymäläinen H-R, Stallones L et al (2013) International perspectives on psychosocial working conditions, mental health, and stress of dairy farm operators. J Agromedicine 18(3):244-255. https://doi.org/10.1080/ 1059924X.2013.796903

Lynch E, Harvois F (2016) Le Beaufort: réinventer le fruit commun. Editions Libel, Lyon

Martín-López B, Leister I, Lorenzo Cruz P, Palomo I, Grêt-Regamey A et al (2019) Nature's contributions to people in mountains: a review. Saunders ME, editor. PLOS ONE. 14(6):e0217847. https:// doi.org/10.1371/journal.pone.0217847.

Mascareño A, Henríquez PA, Billi M, Ruz GA (2020) A Twitter-lived red tide crisis on Chiloé Island, Chile: what can be obtained for social-ecological research through social media analysis? Sustainability 12(20):8506. https://doi.org/10.3390/su12208506

Mastrángelo ME, Pérez-Harguindeguy N, Enrico L, Bennett E, Lavorel S et al (2019) Key knowledge gaps to achieve global sustainability goals. Nat Sustain 2(12):1115-1121. https://doi.org/10.1038/ s41893-019-0412-1

Max-Neef M, Elizalde A, Hopenhayn M (1989) Human scale development: an option for the future. Dev Dialogue.:1-136.

Meyer D, Zeileis A, Hornik K (2006) The strucplot framework: visualizing multi-way contingency tables with vcd. J Stat Softw 17(1):148. https://doi.org/10.18637/jss.v017.i03

Meyer D, Zeileis A, Hornik K (2020) vcd visualizing categorical data. $\mathrm{R}$ package version 1.4-7.

Naik A (2017) In search of farmer wellbeing. Int J Agric Manag 06 1. [accessed 2020 Sep 25]. https://ageconsearch.umn.edu/record/ 287265.

Neuendorf KA, Skalski PD (2009) Quantitative content analysis and the measurement of collective identity. In: Abdelal R, Herrera YM, Johnston AI, McDermott R, editors. Measuring identity. Cambridge: Cambridge University Press. p. 203-236. [accessed 2020 Aug 26]. https://www.cambridge.org/core/product/identifier/ CBO9780511810909A019/type/book_part.

Ostrom E (1990) Governing the commons: the evolution of institutions for collective action. Cambridge; New York: Cambridge University Press (The political economy of institutions and decisions).

Ostrom E (1999) Social capital: a fad or a fundamental concept? In: Social capital: a multifaceted perspective. World Bank. Washington, D.C: Dasgupta Partha, Serageldin Ismail. p. 172-214.

Oteros-Rozas E, Martín-López B, Fagerholm N, Bieling C, Plieninger T (2018) Using social media photos to explore the relation between cultural ecosystem services and landscape features across five European sites. Ecol Indic 94:74-86. https://doi.org/10.1016/j. ecolind.2017.02.009

Pachoud C (2019) Identity, feeling of belonging and collective action in localized agrifood systems. Example of the Serrano cheese in the Campos de Cima da Serra, Brazil. Cah Agric. 28:28. https://doi. org/10.1051/cagri/2019028.

Pachoud C, Delay E, Da Re R, Ramanzin M, Sturaro E (2020) A relational approach to studying collective action in dairy cooperatives producing mountain cheeses in the Alps: the case of the Primiero cooperative in the Eastern Italians Alps. Sustainability 12(11):4596. https://doi.org/10.3390/su12114596

Palomo I, Felipe-Lucia MR, Bennett EM, Martín-López B, Pascual U (2016) Disentangling the pathways and effects of ecosystem service co-production. In: Advances in ecological research. Vol. 54. Elsevier. p. 245-283. [accessed 2020 Aug 25]. https://linkinghub. elsevier.com/retrieve/pii/S0065250415000276.

Partelow S, Jäger A, Schlüter A (2021) Linking fisher perceptions to social-ecological context: mixed method application of the SES framework in Costa Rica. Hum Ecol 49(2):187-203. https://doi. org/10.1007/s10745-021-00228-x

Pascual U, Balvanera P, Díaz S, Pataki G, Roth E et al (2017) Valuing nature's contributions to people: the IPBES approach. Curr Opin Environ Sustain 26-27:7-16. https://doi.org/10.1016/j.cosust. 2016.12.006

Pelenc J, Ballet J (2015) Strong sustainability, critical natural capital and the capability approach. Ecol Econ 112:36-44. https://doi.org/10. 1016/j.ecolecon.2015.02.006

Pelenc J, Bazile D, Ceruti C (2015) Collective capability and collective agency for sustainability: a case study. Ecol Econ 118:226-239. https://doi.org/10.1016/j.ecolecon.2015.07.001

Petway JR, Lin Y-P, Wunderlich RF (2020) A place-based approach to agricultural nonmaterial intangible cultural ecosystem service values. Sustainability 12(2):699. https://doi.org/10.3390/su120 20699

Poppenborg P, Koellner T (2013) Do attitudes toward ecosystem services determine agricultural land use practices? An analysis of farmers' decision-making in a South Korean watershed. Land Use Policy 31:422-429. https://doi.org/10.1016/j.landusepol.2012.08.007 
QSR International (2020) NVIVO (released in March 2020). https:// www.qsinternational.com/nvivo-qualitative-data-analysis-softw are/home.

Quiñones Ruiz XF, Forster H, Penker M, Belletti G, Marescotti A, Scaramuzzi S, Broscha K, Braito M, Altenbuchner C (2018) How are food geographical indications evolving? - an analysis of EU GI amendments. Br Food J 120(8):1876-1887. https://doi.org/10. 1108/BFJ-02-2018-0087

R Core Team (2020) A language and environment for statistical computing. R foundation for statistical computing. Vienna,Austria. http:// www.r-project.org.

Rauschmayer F, Polzin C, Mock M, Omann I (2018) Examining collective action through the capability approach: the example of community currencies. J Hum Dev Capab 19(3):345-364. https://doi. org/10.1080/19452829.2017.1415870

Reed MS, Graves A, Dandy N, Posthumus H, Hubacek K et al (2009) Who's in and why? A typology of stakeholder analysis methods for natural resource management. J Environ Manage 90(5):19331949. https://doi.org/10.1016/j.jenvman.2009.01.001

Ricard D (2015) Dairy cooperatives in the French mountains: heritage, diversity of structures, dynamics of movement. Rev Géographie Alp.(103-1). https://doi.org/10.4000/rga.2751. [accessed 2021 Apr 28]. http://journals.openedition.org/rga/2751.

Rudd MA (2000) Live long and prosper: collective action, social capital and social vision. Ecol Econ 34(1):131-144. https://doi.org/10. 1016/S0921-8009(00)00152-X

Russell R, Guerry AD, Balvanera P, Gould RK, Basurto X et al (2013) Humans and nature: how knowing and experiencing nature affect well-being. Annu Rev Environ Resour 38(1):473-502. https://doi. org/10.1146/annurev-environ-012312-110838

Santini F, Guri F, Gomez y Paloma S, Institute for Prospective Technological Studies (2013) Labelling of agricultural and food products of mountain farming. Luxembourg: Publications Office. [accessed 2020 Sep 24]. https://doi.org/10.2791/67942.

Schermer M, Darnhofer I, Daugstad K, Gabillet M, Lavorel S et al (2016) Institutional impacts on the resilience of mountain grasslands: an analysis based on three European case studies. Land Use Policy 52:382-391. https://doi.org/10.1016/j.landusepol.2015.12.009

Schermer M, Renting H, Oostindie H (2010) Collective farmers marketing inititatives, diversity, contextuality and dynamics. Int J Sociol Agric Food 1-11. https://doi.org/10.48416/ijsaf.v18i1.253

Schröter M, Başak E, Christie M, Church A, Keune H et al (2020) Indicators for relational values of nature's contributions to good quality of life: the IPBES approach for Europe and Central Asia. Ecosyst People 16(1):50-69. https://doi.org/10.1080/26395916. 2019.1703039
Sen A (2000) Development as freedom. 1. Anchor, Books. Anchor Books, New York

Spangenberg JH, Görg C, Truong DT, Tekken V, Bustamante JV et al (2014) Provision of ecosystem services is determined by human agency, not ecosystem functions Four case studies. Int J Biodivers Sci Ecosyst Serv Manag 10(1):40-53. https://doi.org/10.1080/ 21513732.2014.884166

SPM (Syndicat du pays de Maurienne) (2020) Schéma de cohèrence territoriale.

Stojanovic T, McNae HM, Tett P, Potts TW, Reis J et al (2016) The aspect of social-ecological systems: a critique of analytical frameworks and findings from a multisite study of coastal sustainability. Ecol Soc. 21(3). https://doi.org/10.5751/ES-08633-210315. [accessed 2020 Aug 31]. http://www.ecologyandsociety.org/vol21/ iss $3 / \operatorname{art} 15 /$.

Vallet A, Locatelli B, Levrel H, Dendoncker N, Barnaud C (2019a) Linking equity, power, and stakeholders' roles in relation to ecosystem services. Ecol Soc. 24(2). https://doi.org/10.5751/ES-10904240214. [accessed 2020 Aug 25]. https://www.ecologyandsocie ty.org/vol24/iss2/art14/.

Vallet A, Locatelli B, Levrel H, Dendoncker N, Barnaud C (2019b) Linking equity, power, and stakeholders' roles in relation to ecosystem services. Ecol Soc. 24(2). https://doi.org/10.5751/ES-10904240214. [accessed 2020 Aug 25]. https://www.ecologyandsocie ty.org/vol24/iss2/art14/.

Vourvachis P, Woodward T (2015) Content analysis in social and environmental reporting research: trends and challenges. J Appl Account Res 16(2):166-195. https://doi.org/10.1108/ JAAR-04-2013-0027

Weber MA, Caplan S, Ringold P, Blocksom K (2017) Rivers and streams in the media: a content analysis of ecosystem services. Ecol Soc. 22(3). https://doi.org/10.5751/ES-09496-220315. [accessed 2020 Aug 26]. https://www.ecologyandsociety.org/vol22/iss3/art15/.

Wickham H, Averick M, Bryan J, Chang W, McGowan L et al (2019) Welcome to the tidyverse. J Open Source Softw 4(43):1686. https://doi.org/10.21105/joss.01686

Zeileis A, Meyer D, Hornik K (2007) Residual-based shadings for visualizing (conditional) independence. J Comput Graph Stat 16(3):507-525. https://doi.org/10.1198/106186007X237856

Publisher's note Springer Nature remains neutral with regard to jurisdictional claims in published maps and institutional affiliations. 